\title{
Policy Implementation Of Green Space In Bandung City Seen From Power, Interest, And Strategies Of Actor Involved Factor (Study About Park and City Forest)
}

\author{
Tatik Fidowaty \\ Lecturer of Government Science, Unikom \\ Student of Doctoral Program, Unpad \\ Sumedang, Indonesia \\ tatik.fidowaty@email.unikom.ac.id
}

\author{
Nasrullah Nazsir, Utang Suwaryo, and Nandang A. D. \\ Government Science, FISIP \\ Unpad \\ Sumedang, Indonesia
}

\begin{abstract}
The existence of green space is very important in a city. Green space is a place of rain water absorption, air fresheners, flood control, recreation facilities and so fogreen space. Referring to Law No. 26 of 2007 on Spatial Planning, requires that urban managers have a minimum of $30 \%$ green space of its area. Public green space by $20 \%$ and private green space by $10 \%$. Currently, the city of Bandung only has a green space of $14.42 \%$ or an area of $2,077.82 \mathrm{ha}$. The amount is still not in accordance with the ideal amount required. Bandung City Local Government has made Regional Regulation No. 07 of 2011 on the management of green spaces, but in its implementation has not been achieved in accordance with the policy objectives or unsuccessful (unsuccessful implementation).
\end{abstract}

This study examines the implementation of green space policy focusing on green spaces of the public, especially parks and urban forest in view of power factor, interest, and strategies of the actor involved.

The research method used in this research is a descriptive qualitative method. Informant determination technique used with purposive technique. The Technique of collecting data by doing, literature study, observation, in-depth interview, internet searching, and photo documentation.

The result of the research shows that the lack of implementation of green space policy is seen from the power factor, interest, and strategies of the actor involved because of the abuses of authority and function by some actors which resulted in the parks and the Babakan Siliwangi forest being abandoned. In addition, there is also a conflict of public interest versus the commercial interests of the holder of power, it arises because of inconsistent policies of even distribution of development in Bandung.

Keywords—implementation, policy, green space

\section{INTRODUCTION}

Space within the territory of the Unitary State of the Republic of Indonesia is a unified territory which includes land, sea, and air including as natural resources is a gift of God Almighty to the nation of Indonesia to be grateful, protected and managed sustainably for the prosperity of the people in accordance with the mandate contained in Article 33 Paragraph (3) of the 1945 Constitution of the State of the Republic of Indonesia which reads: "The green space and the water and the natural resources contained therein shall be controlled by the State and used for the greatest prosperity of the people". Therefore, the utilization must be arranged and developed in a coordinated spatial pattern so that there will be no destruction of the environment. Implementation of a prudent spatial is the key to creating a harmonious environment.

UU no. 26/2007 concerning the spatial arrangement of Article 1 point 31 states that green space is "extended / lane / and/or clustered areas, whose use is more open, where plants grow either naturally or intentionally planted". Green space consists of public green space and private green space, in Local Regulation (Perda) Bandung City. 07 The year 2011 on green space Article 1 paragraph 9 explained that: "Public green space is green space owned and managed by Local Government which is used for public interest in general. While paragraph 10 says that: "Private green space is the green space belonging to a particular institution, or an individual who uses it for the limited circle, among others, in the form of gardens or yard/building owned by the community/private planted with plants".

The presence of green space is very important in a city. green space is used for recreation, relax and play with family and friends. It is also a place for rainwater absorption, air fresheners, flood control and maintenance of certain ecosystems.

Bandung is the capital of West Java Province. Bandung is known as the city of flowers, the beauty of nature and the cool weather adds to the appeal of Bandung. However, the beauty of this city gradually changes with the rapid pace of development. Development has made many changes to the state of the city, new and modern buildings that serve as shopping centers, offices, homes, industries, and others thrive. These developments also cause spatial problems that ultimately make green spaces increasingly reduced. 
Bandung City Local Government has made Regional Regulation (Perda) no. 07 The year 2011 on Green space Management, but in its implementation has not been achieved in accordance with policy objectives or unsuccessful implementation (unsuccessful implementation). This happens because of various problems such as the lack of capacity and organizational capability of implementing institutions, weak implementation management, conflict of interest between actors, administrators, field officers, target groups and lack of resources (human resources, budget, tools and time ).

In this study researchers interested in researching public green space especially the park and forest city because in Bandung there are many parks that are not in good management. Based on data from the Central Bureau of Statistics (BPS) Bandung City 2015 there are 604 parks in Bandung but only about $40 \%$ (242 pieces) parks that can be managed by DISKAMTAM, it happens because the lack of the number of skilled field human resources in addition as well as limited funding capabilities, supporting facilities for park management operations as well as lack of coordination among SKPD related to the management of green space.

Mayor of Bandung period 2013-2018 Ridwan Kamil is very concerned with the development of parks and take advantage of private parties in the development of these parks, such as the construction of thematic parks for example jomlo park and movie park that managed to become public space and utilize funds corporate social responsibility (CSR) from various companies in Bandung but the parks are quickly damaged due to lack of maintenance and awareness and public awareness.

Then the urban forest as part of the green space that serves to maintain the balance of the environment is also reduced. Reduced forest will lead to disturbed urban ecosystem balance characterized by increasing air temperatures in Bandung, air pollution (increased levels of $\mathrm{CO}$, ozone, carbon dioxide, nitrogen oxide, dust, and arid atmosphere), floods, heavy metal content increased, and decreased groundwater levels.

On Tuesday, September 27, 2011, Babakan Siliwangi Inaugurated as an international city forest by the United Nations Environment Program (UNEP). Babakan Siliwangi area is one of the green space in Bandung which has an area of approximately 3.8 ha. However, the current condition of Babakan Siliwangi urban forest is not as expected. The abuses of authority and function by some parties and the lack of attention from the surrounding community resulted in Babakan Siliwangi being abandoned. Conflict of public interest versus commercial interest in Babakan Siliwangi arises because of the inconsistency of development equalization policy of Bandung City. This can be seen from the news submitted by Pikiran Rakyat Online on July 1, 2011, at 18:26 are:
BANDUNG (PRLM) .- After the Special Committee on the Draft of Regional Regulation (Raperda Pansus) Spatial Plans (RTRW) of Bandung City House of Representatives hinted that the permission of physical development in Babakan Siliwangi area (Basil), turn Commission C DPRD Bandung stated their approval on the policy. Prohibition of physical construction is only applied to green areas that have not been built previously.

"It's hard to make Basil one hundred percent green space without physical development. Former buildings have existed for a long time. That is, development has always been allowed. We escorted it. However, development is allowed only in the old footprint, "said Vice Chairman of Commission C DPRD Bandung Cecep Hendarwan, Friday (1/7).

"Basil returned to the starting position. Development is allowed on the old footprint, "said the former Chairman of the RTRW Tomsom Dabul Qomar Rupture Committee shortly before the Raperda was passed into Perda on Thursday (30/6).

Previously, in the midst of a strong urge by residents to return Basil area to one hundred percent of the green space, Mayor Dada Rosada also hinted that physical construction of the old site may be allowed. "I do not think there is a pure green space. Even in the jungle, there is always a building, "he said after World Environment Day celebration on Thursday (16/6).

With the enactment of the RTRW law which opens opportunities for physical development in the old site of Baksil, the opportunity to grant building permit (IMB) to PT. Esa Gemilang Indah (EGI), as the manager of Baksil area, wide open. Planned, on the old footprint, will be built restaurant to support the activities of sports and tourism are allowed in the area.

\section{METHOD}

The research method used in this research is a descriptive qualitative method. Informant determination technique used with purposive technique. Data collection techniques by conducting, library study, observation, in-depth interview, internet searching, and photo documentation

\section{RESULTS}

Before you begin to format your paper, first write and save the content as a separate text file. Keep your text and graphic files separate until after the text has been formatted and styled. Do not use hard tabs, and limit use of hard returns to only one return at the end of a paragraph. Do not add any kind of pagination anywhere in the paper. Do not number text headsthe template will do that for you. 
Green space conditions in urban areas have decreased over time along with the dynamic development of the city, as well as changing environmental conditions worse over the course of the day the existence of green space is increasingly pressed with the needs of urban communities. Bandung City Government has tried to increase the green space, it can be seen in the graph below:

\section{Graph 1}

The Development of Bandung Green Space Urban Period 2009-2015

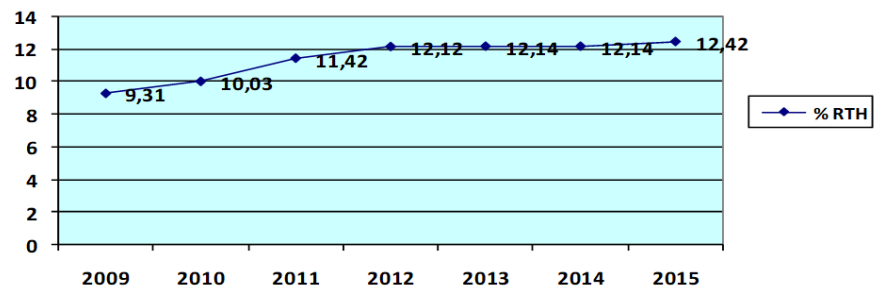

Source: DISKAMTAM Bandung in 2015

Based on the graph above Bandung green space tend to increase. However, in 2014 the percentage of green space is still not the same as the year 2013 of $12.14 \%$ and in 2015 rose to $14.42 \%$ or an area of $2,077.82$ ha. The amount is divided into public open space of $6.09 \%$ or 1.018 .55 ha and private green space area of $5.33 \%$ or 891.85 ha. The quantity of green space is also far from the ideal conditions required, as stated in Regulation No. 18 of 2011 on the spatial plan of Bandung 2011-2031 Article 88a, namely: "To fulfill the green space by $30 \%$ (thirty percent) of total area city area ".

Green space 30\% refers to government provisions based on Law no. The proportion of green spaces in urban areas shall be at least 30 (thirty) percent from the total area of the city "and in paragraph (3) states that" The proportion of open space public green on urban areas of at least 20 (twenty) percent of city area".

If you refer to Law no. 26 of 2007 on Spatial Planning which requires urban managers have at least $30 \%$ of the green space then the city of Bandung should have green space of $5,018.90$ ha of the total area of Bandung for 16.729.65 ha. The green space gain in 2015 of $14.42 \%$ or $2,077.82$ ha is also not in accordance with the target of the strategic plan (renstra) DISKAMTAM Bandung in 2013-2018 which targets the green space area of 2015 by $16 \%$, for more details can be seen on the chart below:

Graph 2

Bandung Target green space Period 2013-2018

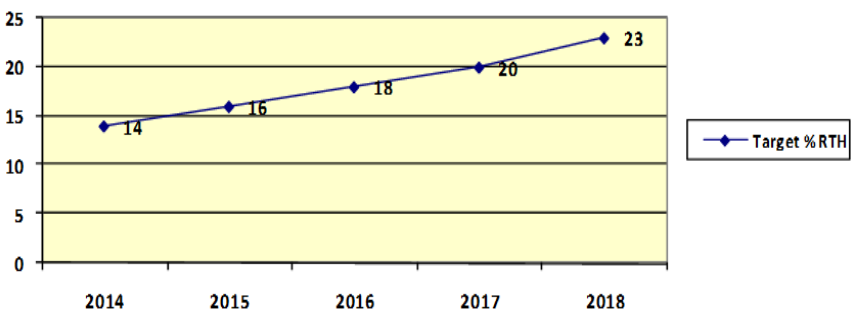

Source: Renstra DISKAMTAM Bandung year 2013-2018
The presence of green space is important in controlling and maintaining the integrity and quality of the environment. The control of urban development should be done proportionally and be in balance between development and environmental functions.

Lack of green space proportion in Bandung first caused by uneven development and land mutation that happened because of high economic value in urban area, and also because of failure of various regulation which regulates green space layout. This is evidenced by the still widespread development in areas that should be destined for water catchment areas. In addition, the use of land for settlements in Bandung increased every year to reach $51.05 \%$ as shown in the following graph:

Graph 3

Land Use in Bandung City 2012

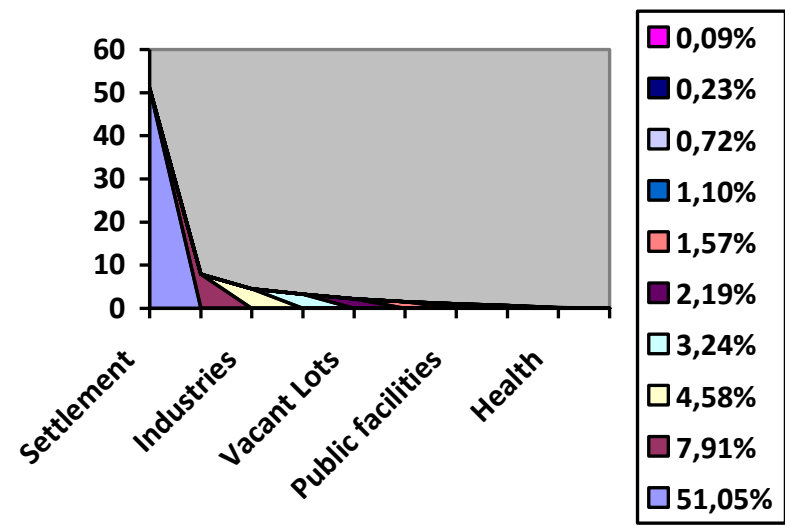

Source: BPS of Bandung City in 2012

Increased land use for settlements in the city of Bandung due to the increasing number of residents in the city of Bandung. The denser population causes changes in urban structures and the increasing land area. Population growth rate in Bandung reaches $1.26 \%$ per year. For more details about population growth can be seen in the following graph:

\section{Graph 4}

Development of Population of Bandung City Year 2007-2012 and Projection Year 2013-2018

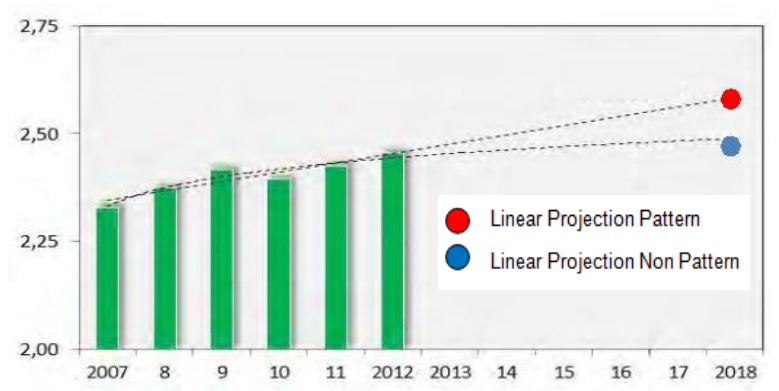

Sumber : BPS of Bandung City in 2012 
Based on these data, it can be seen that the population tends to increase. Projection is evidenced by the number of residents of Bandung today reached 2,748,733 Souls. Which consists of the number of male population of 1.404 .918 people and the number of female population of 1.343 .815 people at this time based on data from DISDUKCAPIL Bandung in 2014. This increase in population is Walgreen space noting because it will affect the land settlement and impact on the availability of green space.

Another cause is the lack of green space also because of the many illegal buildings built on land intended for green space and still many parties who think that the green space in the middle of the big city is clearly not profitable and almost no economic value when compared with the construction of a mall, settlements, and other social facilities. In fact, GREEN SPACE Public based on Perda Bandung City. 07 The year 2011 on the management of GREEN SPACE Article 18 consists of: "a. Park and forest city, b. Pathway green, c. Green border river, $d$. The green line of high voltage electrical network, e. Public cemetery (TPU), and f. The nursery has a function that is not measurable by the economic calculation alone ". GREEN SPACE serves as an air filter and water catchment area (ecological function) and also serves as a means for city residents to interact and recreate (social and cultural functions), as well as means in order to improve the comfort and beauty of the environment oriented to the increase in harmonization and balance of environmental quality urban life (aesthetic function).

Power, interest, and strategies of actors involved or power, interests, and strategies of the actors involved are among the factors that determine the success of the green space in the city of Bandung. Support of influential interest groups in the implementation of policies determines the success of implementation. These interest groups are at the same time key actors to be reckoned with: politicians, businessmen, religious leaders, customary leaders and social institutions (NGOs). The success of the policy implementation is closely related to the performance of the bureaucracy. Saefullah reveals that:

"The performance of the bureaucracy is the result of the attractiveness of the various forces that each bring different values, including legislative institutions, official organizations, professional organizations, political organizations and so green space. In other words, nature and performance are subject to change depending on the dominance or the stronger emphasis point in the attraction. Ideally, it should be a compromise of these values but with frequent internal conflicts, it represents the difficulty of achieving compromise "(Saefullah, 2010: 22).

In a policy, it is also necessary to take into account the strength, power, interests, and strategies used by the actors involved to facilitate the execution of a policy to proceed according to plan and avoid various conflicts.

\section{CONCLUSION}

Depletion of the existence of vacant land, many practices change the function of protected areas into cultivation for example in Babakan Siliwangi area, and the most influential on the depletion of green space in Bandung is the community's need for land in urban areas where the vacant land is available is thinning, consequently many changes in land function and the impact that occurs directly is the existing green space, from time to time increasingly threatened its existence. The public interest versus the personal interests of the rulers has exacerbated the lack of green space.

\section{Acknowledgment}

On this occasion, the author would like to say thanks as much as possible to:

1) The Unikom Rector, Dr. Ir. Eddy Soeryanto Soegoto who has provided support both morally and materially

2) The Ministry of Research, Technology and Higher Education of the Republic of Indonesia has provided educational scholarships

3) The promoters who have provided many directives and inputs are Mr. Nasrullah Nazsir, Utang Suwaryo, and Nandang Alamsah Deliarnoor

4) My parents, younger and elder sisters

5) Co-workers

\section{References}

[1] Atmojo, Suntoro Wongso. 2007. Menciptakan Taman Kota Berseri. Solo: Solo Pos.

[2] Arifin H. S dan Nur hayati. 2000. Pemeliharaan Taman. Jakarta: Penebar Swadaya.

[3] Agustino, Leo. 2006. Dasar-Dasar Kebijakan Publik. Bandung: CV. Alfabeta.

[4] Anderson, James E. 1979. Public Policy Making. New York: Hal, Rinehart and Winston.

[5] Creswell, John W. 2013. Qualitative Inquiry \& Research Design, Choosing Among Five Approaches (third edition). Washington DC: SAGE

[6] ------. 2013. Research Design Pendekatan kualitatif, kuntitatif dan mixed. Terjemahan Ahmad Fawaid. Yogyakarta: Pustaka Pelajar

[7] Dahlan, E.N. 1992. Hutan Kota Untuk Pengelolaan dan Peningkatan Kualitas Lingkungan Hidup. Bogor: Asosiasi Pengusaha Hutan Indonesia.

[8] ------. 2004. Membangun Kota Kebun (Garden City) Bernuansa Hutan Kota. Bogor: IPB Press.

[9] Fandeli, C. 2004. Perhutanan Kota. Jogjakarta: Fakultas Kehutanan Universitas Gadjah Mada.

[10] Grindle, Merilee S. 1980. Politics and Policy Implementation in The Third World. New Jersey: Princeton University Press.

[11] Irwan, Z.D. 1997. Tantangan Lingkungan dan Lansekap Hutan Kota. Jakarta: Pustaka Cidesindo.

[12] Nazaruddin. 1996. Penghijauan Kota. Jakarta: Penebar Swadaya.

[13] Saefullah, H. A. Djadja. 2007. Pemikiran Kontemporer Administrasi Publik, Perspektif Manajemen Sumber Daya Manusia dalam Era Desentralisasi. Bandung: LP3AN FISIP Unpad.

[14] Wahab, Abdul. 1997. Analisis Kebijaksanaan: dari Formulasi ke Implementasi Kebijakan

[15] Undang-undang Republik Indonesia No. 26 Tahun 2007 Tentang Penataan Ruang

[16] Peraturan Pemerintah No. 63 Tahun 2002 tentang Hutan Kota 
[17] Permendagri No. 01 Tahun 2007 tentang Penataan Ruang Terbuka Hijau Kawasan Perkotaan

[18] Peraturan Mentri PU No 5/PRT/M/2008 tentang Pedoman Penyediaan dan Pemanfaatan GREEN SPACE di Kawasan Perkotaan

[19] Peraturan Daerah Kota Bandung No. 07 Tahun 2011 Tentang Pengelolaan Ruang Terbuka Hijau

[20] Peraturan Daerah Kota Bandung No. 18 Tahun 2011 Tentang Rencana Tata Ruang Wilayah Kota Bandung Tahun 2011-2031

[21] Rencana Strategis Dinas Pertamanan dan Pemakaman (DISKAMTAM) Kota Bandung 2013-2018
[22] Rencana Strategis Dinas Tata Ruang dan Cipta Karya (DISTARCIP) Kota Bandung 2013-2018

[23] http://portal.bandung.go.id/site/sdk-program

[24] http://distarcip.bandung.go.id/index.php/main/home

[25] http://diskamtam.bandung.go.id/index.php/main/home

[26] http://ppid.bandung.go.id/profil-ppid/

[27] http://ejournal.forda-mof.org/ejournallitbang/index.php/JAKK/article/view/717

[28] http://sappk.itb.ac.id/jpwk2/wp-content/uploads/2013/11/V2N3Strategi-Pengadaan-Lahan-Untuk-Ruang-Terbuka-Hijau-Di-KotaBandung-.pdf 